JAGGER, Alison and BoRDo, Susan (1989) editors, Gender, Body, Knowledge: Feminist Reconstructions of Being and Knowing, New Brunswick: Rutgers University Press.

RoSE, Hilary (1983) 'Hand, Brain and
Heart: Towards a Feminist Epistemology for the Natural Sciences' in HARDING and O'BARR.

SMITH, Dorothy (1987) The Everyday World as Problematic: a Feminist Sociology, Milton Keynes: Open University Press.

\section{Texts, Facts and Femininity: Exploring the Relations of Ruling}

\section{Dorothy E. Smith}

Routledge: London 1990

ISBN 0415032318 Hbk £30.00

I first encountered Dorothy Smith's work in a piece in the Socialist Register (Miliband and Saville, 1983) that refreshingly challenged monogendered Marxist accounts of class and family; then again representing the 'feminist standpoint' approach in The Everyday World as Problematic. In this collection of essays, dating back to the late $1970 \mathrm{~s}$, and her famous piece ' $\mathrm{K}$ is Mentally Ill', Smith sets out her main preoccupations as a feminist sociologist. The terms in the title could equally be 'discourse, practice and feminism'. First, she stresses the importance of ethnomethodology and discourse theory for understanding contemporary power relations. But second, she retains a broadly Marxist understanding of the materiality of texts and of the social practices within which they are situated. She remains enough of a realist to insist that there is a world which defines itself independently of our inquiry. And third, it is feminism which provides the vantage-point for her critique of mainstream sociology and her critical usage of both Marxism and discourse theory.

Sociological discourse, she argues, with its emphasis on rationality, objectivity and scientificity, is deeply implicated in the relations of ruling. Her counter to this is to explore the social from the standpoint of women's experience. She is not referring here to a particular kind of knowledge so much as a discursive strategy wherein the speaker lays claim to authority in speaking of her everyday life. This is 'insiders' sociology'. Throughout the text 'the sociologist' is referred to as 'she', reminding us continuously that sociology is always written from within particular standpoints. 'Social reality', she reminds us, is not external to she who experiences, makes, or observes it' (p. 53). Sociology retains a geocentric cosmology, treating the world as fixed when we have to shift to a heliocentric cosmology. It is only when the observer finds 'herself' moving in relation to what 'she' observes that there is scope for an 'accurate' account of the (solar) system.

Sociology, for Smith, has been naive about texts, continuing to treat them as a source of information about something else, rather than as phenomena in their own right which actively structure social and power relations. The key characteristic of modernity, she says, is that social relations are mediated by texts; discourses are embedded in the sets of everyday and institutional contexts in which subjects act. Marxists must accept that textual analysis has now become crucial for understanding the ubiquitous and generalizing organization of the ruling relations. She stresses the emergence of 'public, textually mediated discourse as a new form of social relation transcending and organising local settings' (p. 167).

Smith credits ethnomethodology, Garfinkel in particular, with discovering the text as a significant constituent of social relations, and Foucault with developing these earlier insights. Discourse theorists dis- 
place the analysis from the text as originating in writer or thinker, to the ongoing intertextual process. While in agreement with them about the importance of working within the text, she shares the standard Marxist critique of Foucault of denying the subject any agency, and repositions the textual in the social practices in which they are embedded as well as organizing.

Through the book, Smith offers many case studies ranging from the social construction of mental illness, through agenda setting at a public meeting, and the construction of 'news', to femininity as a discursive construction. Smith makes the point that, while it was politically important to introduce the concept of gender into feminist thought, the fixity of gender creates problems of exploring the social as open-ended, as process. She recognizes that 'our contemporary forms of "femininity" have been vested in a textually mediated discourse from the beginning' (p. 169). She wants to explore femininity as the actual social relations of a discourse mediated by texts in which women are active as subjects and agents. Her method is to position the inquirer in the actualities of her world, the same world in which this text is written and read; to begin with the ordinary and unanalysed ways we know what we are talking about when we use the concept.

This is insiders' sociology where the text is treated as a means of access, a direct line to the relations it organizes. Femininity is an effect of numerous discourses across a variety of local sites. Along with the discourses vested in women's magazines and television, cosmetics counters and fashion displays and so on, are the practices through which (real) women operate these discourses. The analysis preserves the presence of women as active subjects as the inquirer is positioned in the actual talk women do in relation to the texts, and the skills that are involved in producing oneself to real- ize the textual images. Jane One is the secret agent who we meet 'backstage', who has done the work or knows how to do it; Jane Two is the feminine subject-in-discourse. The sense of the detailed knowledge and skills involved in constructing 'femininity', and the pleasures of applying them, despite its overall oppressiveness, are rather similar to Frigga Haug's in Female Sexualisation (Verso, 1987). Smith fastens her hopes on Jane One, who has the possibility of defining herself in multiple ways, deriving pleasure from decorating her body and experimenting with who she would like to be.

I find it difficult to know to whom this book is directed. It is not an easy read, and provides little in the way of textual pleasure. Perhaps because it consists of a series of essays developed over quite a long period of time, the text is convoluted and repetitive. At the same time, the central ideas now seem obvious and fairly straightforward. The book does not have a great deal to contribute to current feminist debates but rather remains engaged with debates from the past concerning Marxism and ethnomethodology. I imagine an audience of wellmeaning socialist sociologists of the old style, or perhaps orthodox socialist-feminists of the mid-seventies vintage, who are worried about 'relativism' and the rejection of materialism - that this book may be attempting to convince. For it shares many of their concerns, while attempting to add in, in a reassuring way, the insights of discourse theory and cultural analysis.

To anyone familiar with the literatures of cultural studies or poststructuralism, these insights will seem basic indeed. Compared with the neo-Lacanian accounts of femininity, Smith's dual subject seems particularly limited. Smith's 'standpoint of women' would also seem to come into conflict with poststructuralist ideas, and with her own 
remarks about trying to avoid treating gender as fixed and static. Does a feminist standpoint really provide us with a more accurate picture of the world? I can see that it may provide us with a more politically useful one. But accurate? This still assumes that there is a world out there, backstage, that texts can describe with greater or lesser degrees of accuracy. This is hard to reconcile with intertextuality and must make us wonder about the status of 'facts', the middle term in her title. Although, for Smith, the facts are socially constructed, there is still a reality which is knowable outside of textual discourse. She argues that poststructuralism, though working within the textual, blocks off any possibility for an escape hatch for inquiry beyond the textual surface of discourse. There has to be such an escape hatch, she insists, or human agency is denied, and the standpoint of women has already provided one. On the basis of her 'Femininity as Dis- course' I do not find this very convincing. Jane One does not inspire me as a model of feminist agency; neither do Jane's possibilities for subversion or resistance or even pleasure seem very inviting. The book synthesizes a mix of characteristically North American versions of ethnomethodology, Marxism and feminism. It is likely to be received more favourably there than in other parts of the world. Those who ground their politics on a notion of the strength of women's experience are also likely to find it more satisfying than those who are inclined towards deconstruction.

\section{Rosemary Pringle}

\section{References}

SMITH, Dorothy E. (1983) 'Women, Class and Family' in MILIBAND, Ralph and SAVILLE, John (1983) editors, The Socialist Register 1983 London: The Merlin Press, pp. 1-44.

\section{Essentially Speaking: Feminism, Nature and Difference}

\section{Diana Fuss}

Routledge: London 1990

ISBN $0415901332 \mathrm{Pbk} £ 7.99$

ISBN $0415901324 \mathrm{Hbk} £ 30.00$

For many feminists, the essentialism versus social constructionism debate has arrived at an impasse. From the perspective of the social constructionists, the argument that women's experience can be theorized as a universal category leads to an ahistorical conception of women's oppression and dangerously suppresses the rich differentiation among women. For essentialists, the weakening of essences through the social constructionist critique contributes to an erosion of the basis for subjectivity and solidarity: if there is no such thing as 'women' as a univer- sal class (or 'lesbians', 'gays', 'blacks', etc.), but only contingent groupings of different subject-positions which become effective only in specific contexts, then how can we organize collective action? How can we demand rights for women (or lesbians, gays, blacks, etc.) without assuming that such a subject truly exists?

Diane Fuss's book, Essentially Speaking, is an important intervention in this debate. Through a discussion of poststructuralist theory, and reviews of essentialism/ antiessentialism debates in French feminism, Afro-American literary criticism, lesbian and gay theories of identity and feminist pedagogy, Fuss develops an original and insightful argument. Her approach can be loosely described as discourse analysis. Instead of evaluating essentialism as good or bad, as progressive or reactionary, each instance of essentialist discourse is read strategically. 